DOI:

\title{
Türkiye'deki Sürdürülebilir Yükseköğretim Yapılarının Etkin Kaynak Yönetimi Kapsamında Değerlendirilmesi ${ }^{1}$
}

\section{Melisa UYGUN UGUTMEN ${ }^{1 *}$, Gözde ÇAKIR KIASIF²}

\author{
1, 2 Haliç Üniversitesi, Mimarlık Fakültesi Mimarlık Bölümü, İstanbul, Türkiye \\ ${ }^{1}$ ORCID ID:orcid.org/ 0000-0002-5009-2009 \\ 2 ORCID ID:orcid.org/ 0000-0002-7734-4990
}

*Sorumlu Yazar e mail: gozdecakir@halic.edu.tr

Geliş Tarihi: 23.01 .2020

Kabul Tarihi: 04.03 .2020

Atıf/Citation: Uygun Ugutmen, M. ve Çakır Kiasif, G. “Türkiye'deki Sürdürülebilir Yükseköğretim Yapılarının Etkin Kaynak Yönetimi Kapsamında Değerlendirilmesi”, Haliç Üniversitesi Fen Bilimleri Dergisi 2020, 3/1: 109-137.

\section{Araştırma Makalesi/ Research Article}

\section{Özet}

19.yüzyılın sonlarında sanayi devriminin etkisi ve 2000'li yıllarda küreselleşmenin hız kazanmasıyla birlikte doğal kaynakların kontrolsüzce kullanımı çevresel felaketlerin ortaya çıkmasına neden olmuştur. Bu durum ile mücadele etmek için yapı endüstrisi sürdürülebilir yapım teknolojilerini benimsemeye başlamıştır. Çalışma kapsamında Türkiye' deki yükseköğretim yapılarının etkin kaynak kullanımı ile kalkınma adına ciddi faydalar sağlayabileceğinin ortaya konulması amaçlanmaktadır. Kaynaklarını etkin kullanabilen eğitim yapılarında öğrenim gören öğrencilerde sürdürülebilirlik bilincinin oluşturulabileceği öngörülmektedir. Çalışma kapsamında Türkiye'nin farklı bölgelerinde yer alan dokuz adet yüksekögrretim yapısı ele alınmıştır. Bu yapılar; Yeditepe Üniversitesi, Uşak Üniversitesi 1 Eylül Kampüsü Merkezi Derslik Bloğu, Piri Reis Üniversitesi, Namık Kemal Üniversitesi Tıp Fakültesi Morfoloji Binası, Özyeğin Üniversitesi Mühendislik Fakültesi ve Öğrenci Merkezi, Uludağ Üniversitesi Devlet Konservatuvarı, TOBB Ekonomi ve Teknoloji Üniversitesi Öğrenci Konukevi Yapıları, Sabancı Üniversitesi Nanoteknoloji Araştırma ve Uygulama Merkezi, ve İzmir Ekonomi Üniversitesi Güzel Sanatlar ve Tasarım Fakültesidir. Çalışmada yöntem olarak alanyazın taraması yapılmış, çalışmadaki birçok üniversiteye gidilip yerinde tetkikler gerçekleştirilmiş, konu ile ilgili uzman kişilerle görüşülmüştür. Suyun, malzemenin ve enerjinin hangi yöntem ve uygulamalarla binalarda etkin olarak kullanılabileceği ortaya konulmuştur.

Anahtar Kelimeler: Sürdürülebilirlik, Etkin kaynak yönetimi, Eğitim yapıları.

1 Bu makale Melisa Uygun'un Yüksek Lisans tezinden üretilmiştir. 


\title{
Assessment of Worker Attitudes in Regards To Occupational Health and Safety in Construction Projects in Turkey
}

\begin{abstract}
With the effect of the Industrial Revolution in the late 19th century and the acceleration of globalization in the 2000s, the uncontrolled use of natural resources has caused the emergence of environmental disasters. To combat this situation, the building industry has started to adopt sustainable construction technologies. The scope of our study aims to display the great benefit to our progress with the effective use of the source of structures of higher education. It is anticipated that the students who are educated at the institutions of education, which can use their resources effectively, are seen tended to form the consciousness of sustainability. Under the study, four higher education structures in different regions of Turkey were discussed. These structures are; Yeditepe University, Uşak University September 1 Campus Center Classroom Block, Piri Reis University, Namık Kemal University Faculty of Medicine Morphology Building, Özyeğin University Faculty of Engineering and Student Center, Uludağ University State Conservatory, TOBB Economy and Technology University Student Guesthouse Structures, Sabanc1 University Nanotechnology Research and Application Center and İzmir University of Economics Faculty of Fine Arts and Design. In this study, literature review was applied as a method, many universities in the study were visited and on-site examinations were carried out, experts of the related area were interviewed. With which methods and technics that water, material and energy can be used efficiently in buildings are put forward.
\end{abstract}

Keywords: Sustainability, Efficient resource management, Education structures.

\section{Giriş}

Günümüzde küresel 1sınma, buzulların erimesi, biyoçeşitliliğin azalması, su kaynaklarının yıpranması, ormansızlaşma gibi çevresel felaketler nedeniyle dünyanın ekolojik dengesi bozulmuştur. Küreselleşme ile dünya genelinde meydana gelen enerji, malzeme ve su krizlerinin baş sorumlulardan biri olarak görülen yapı sektörü, üzerine düşen sorumluluğu yerine getirerek kaynaklarını etkin kullanabilen yapılar inşa etmeye başlamıştır [1]. Çalışma kapsamında Türkiye'deki 
yükseköğretim yapıları kaynak yönetimi kapsamında ele alınacaktır. Sürdürülebilir bir kaynak yönetimi enerjinin, suyun ve malzemenin etkin kullanılmasıyla gerçekleştirilmektedir. Enerjinin etkin kullanımında doğalgaz, petrol, kömür gibi enerji kaynaklarının çevreye zarar vermesi ve sınırlı oranda olmaları nedeniyle yenilenebilir enerji kaynaklarının kullanımı büyük önem arz etmektedir. Malzemenin etkin kullanımı ise, yapıların uygun bir şekilde boyutlandırılıp malzemelerin titizlikle seçilmesi ile mümkün olmaktadır. Geri dönüşüm teknolojileri ve mevcut strüktür rehabilitasyonu ile ciddi malzeme tasarrufları elde edilmektedir. Dünyada belirli bir oranda olan ve arttırılamayan su kaynaklarının yapılarda etkin bir biçimde kullanılması ise yağmur sularının, gri suların değerlendirilmesi, su etkin ekipman tercihi ve peyzaj alanlarının etkin sulanması ile mümkün olmaktadır [2].

Dünya genelindeki toplam enerji tüketiminde ilk sıralarda yer alan ve yaşanılan enerji krizlerinde başrolü üstlenen yapı sektörü, hasarlarını telafi edebilmek için sürdürülebilir ve enerji etkin yapım sistemlerine yönelmiştir.

\section{1. Çalışmanın amacı}

Kaynakları etkin kullanabilen yükseköğretim yapıları hiç şüphesiz ki diğer standart yükseköğretim yapılarına göre ülke kalkınması için çok daha faydalıdır. Çalışmadaki amaç, Türkiye'deki yükseköğretim yapılarının hangi teknoloji ve uygulamalarla kaynaklarını etkin olarak kullanabileceğini ortaya koymaktır. Ayrıca kaynakları etkin kullanabilen yapıların klasik yöntemlerle inşa edilmiş yapılar için örnek teşkil etmesi öngörülmektedir.

\section{2. Çalışmanın kapsamı ve yöntemi}

Türkiye'de artan genç nüfus ve okuma yazma oranının artması ile birlikte birçok eğitim yapısı inşa edilmektedir. Bu yapıların sürdürülebilir nitelikler taşıması ülke kalkınması adına büyük önem taşımaktadır. 
Yükseköğretim yapılarının LEED ve BREEAM gibi sürdürülebilir sertifika sistemlerine sahip olması kaynakların etkin kullanımı adına büyük önem taşımaktadır. Bu sertifika sistemleri ile yapılar daha titiz, kontrollü ve ölçümlere dayalı olarak inşa edilmektedir. Ancak sürdürülebilirlikte tek gösterge hiç şüphesiz ki sertifikalar değildir. Türkiye'de sertifikasız ancak sürdürülebilir yapım ilkeleriyle inşa edilen birçok yükseköğretim yapısı bulunmaktadır. Çalışma kapsamında Türkiye'nin farklı bölgelerinden sürdürülebilir tasarım ilkeleriyle inşa edilmiş dokuz adet yükseköğretim yapısına yer verilecektir. Ele alınan yapıların hangi teknoloji ve uygulamalarla kaynakları etkin kullandığı ortaya konulacak ve elde edilen veriler üzerinden genel bir durum tespiti yapılacaktır. Çalışmada yöntem olarak alanyazın taraması yapılmıştır. Konu ile ilgili alan indeksli, uluslararası ve ulusal hakemli birçok dergi taranmıştır. Doktora ve yüksek lisans tezleri ulusal tez merkezinin resmi internet sitesinden temin edilmiştir. Uluslararası-ulusal birçok kongre ve sempozyumdaki sunulan bildiriler incelenmiştir. Çalışmada ele alınan birçok üniversiteye gidilip yerinde tetkikler yapılmış, öğrenciler ve konuyla ilgili uzman kişilerle görüşmeler gerçekleştirilmiştir.

\section{Kuramsal Çerçeve: Türkiye’deki Yükseköğretim Yapılarında Etkin Kaynak Yönetimi}

Yükseköğretim kurumları gerek çalışanları, gerekse öğrencileriyle oldukça kalabalık bir nüfusa sahiptir. Birçok binayı, otopark alanını, yeme-içme birimlerini ve yeşil alanları bünyesinde barındırabilen kampüsler, bulunduğu yere sağladığı faydalar yanında negatif etkiler de yaratabilmektedir. $\mathrm{Bu}$ nedenle, yükseköğretim kurumlarının sürdürülebilir olmaları, hem kendi kirletici unsurlarını azaltmak açısından, hem de topluma öncülük etme ve örnek olma açısından son derece önemlidir. Gün boyu çok sayıda ve farklı kullanıcı tarafından kullanılan yükseköğretim yerleşkelerinde; bina sayısı, kullanıcı sayısı, arazi kullanımı gibi etkenlere bağlı olarak hammadde, su, enerji ve yakıt 
tüketimi oldukça fazladır. Bu nedenle, yükseköğretim kurumlarında kaynakların etkin kullanımı son derece önem arz etmektedir [3].

\subsection{Sürdürülebilirlik ve kaynakların etkin kullanımı}

Sürdürülebilirlik, Latince kökü “subtenir”, yani “ korumak” anlamına gelmektedir. [4] Toplumun, ekosistemin ya da devamlılıği olan herhangi bir sistemin, temel kaynakların tükenmesini engelleyerek, gelecek zamana dek işlerliğini devam ettirmesi, sürdürülebilirlik olarak tanımlanabilir [5]. Sürdürülebilir kalkınma kavramı, ekonomi, toplum ve çevre kavramları arasında inşa edilmek istenen dengenin, yeni bir ifade şekli olarak ortaya çıkmıştır. Bu ifadenin, ilk olarak Uluslararası Doğa ve Doğal Kaynakları Koruma Birliği (IUNC) aracılığıyla gerçekleştirilen "Dünya Koruma Stratejisi” adlı raporda ele alındığ 1 görülmüştür. Sürdürülebilirlik kavramı, Birleşmiş Milletler Çevre ve Kalkınma Komisyonunca hazırladığı ve 1987 tarihinde açıklanan "Ortak Geleceğimiz" adlı raporla tüm dünyaya yayılmaya başlamıştır [6].

Sürdürülebilir mimarlık ise mevcut şartlar altında ve varlığını sürdürdüğü her dönemde, nesilden nesle aktarımı önemseyerek öncelikle yenilenebilir enerji kaynaklarının kullanımını gözeten; çevre ile dost, güneşi, suyu, rüzgârı ve içinde bulunduğu tüm alanı etkili biçimde değerlendiren; insanların, sağlık ve yaşam standartlarını güvence altına alan yapısal tasarımların tümüdür (Şekil 1). Yani, insanların barınma ihtiyaçlarını, mevcut olan doğal çevrenin varlığını ve devamlılığını tehlikeye atmadan inşa etmektir. Yapıların yaşam döngüsünde yani ham maddenin çıkarılmasından başlayarak işlenmesi, nakliyesi, yapıların inşası, kullanımı ve yıkımına kadarki tüm süreçlerde sürdürülebilir uygulamalar benimsenmektedir [27]. 


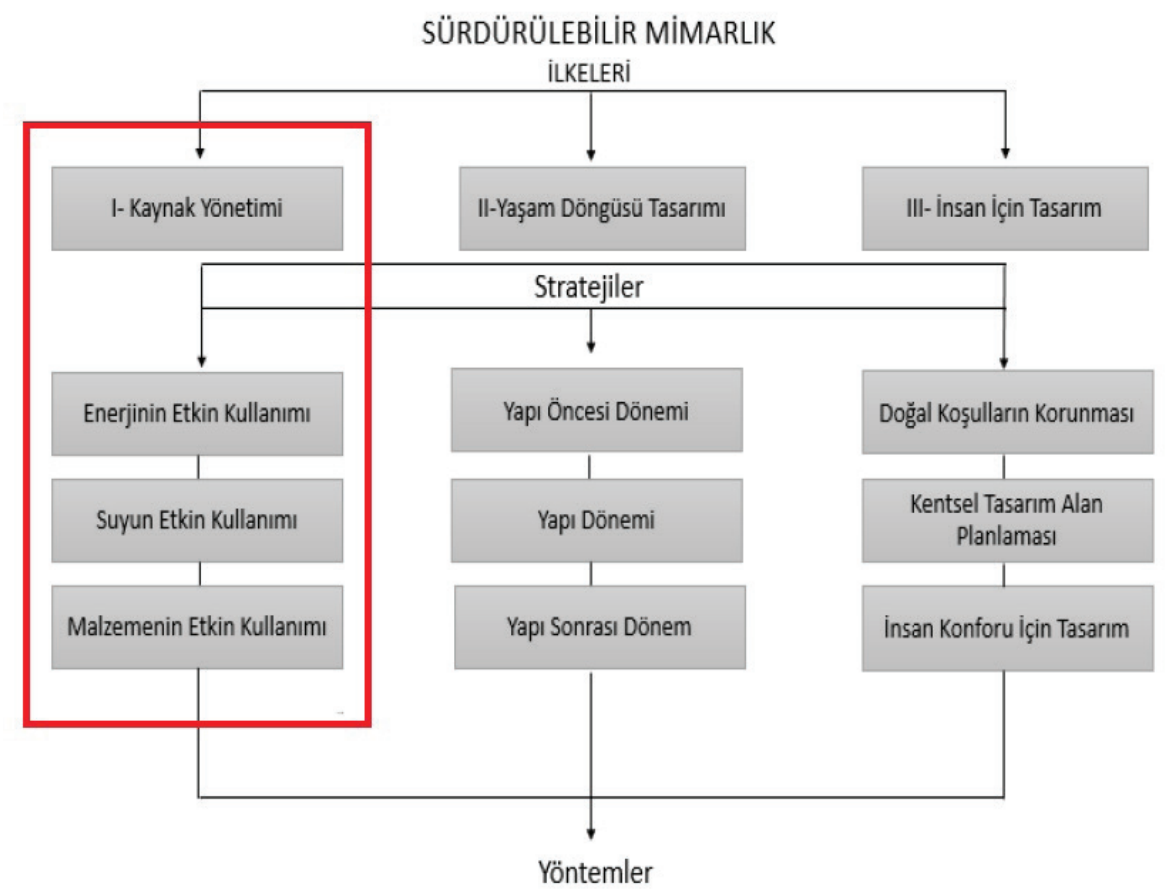

Şekil 1. Sürdürülebilir Mimarlık İlke, Strateji ve Yöntemler [7]

Bir yapıyı oluşturmak üzere kullanılan kaynaklar başka bir deyişle girdiler, işlevini tamamladıktan sonra çıktıları oluşturmaktadır. Yapım süresince girdileri ve çıktıları oluşturan ham madde ve/veya ürünlerde sürekli bir akış söz konusudur. Yapı yaşam döngüsünde faydalı ömrünü tamamladıktan sonra yıkım ile ortaya çıkan atıklar, bertaraf edilmekte ya da uygun malzemeler ve bileşenler olarak kaynak oluşturmak üzere geri dönüştürülmektedir [8]. Kaynak yönetimi, başka bir deyişle kaynakların etkin kullanımı yapıların tüm yaşam döngüleri boyunca enerjiyi, suyu ve malzemeyi verimli bir şekilde kullanma esasına dayanmaktadır. Şekil 2'de hangi yöntemler ile kaynakların etkinliğinin sağlanabileceği gösterilmiştir. 


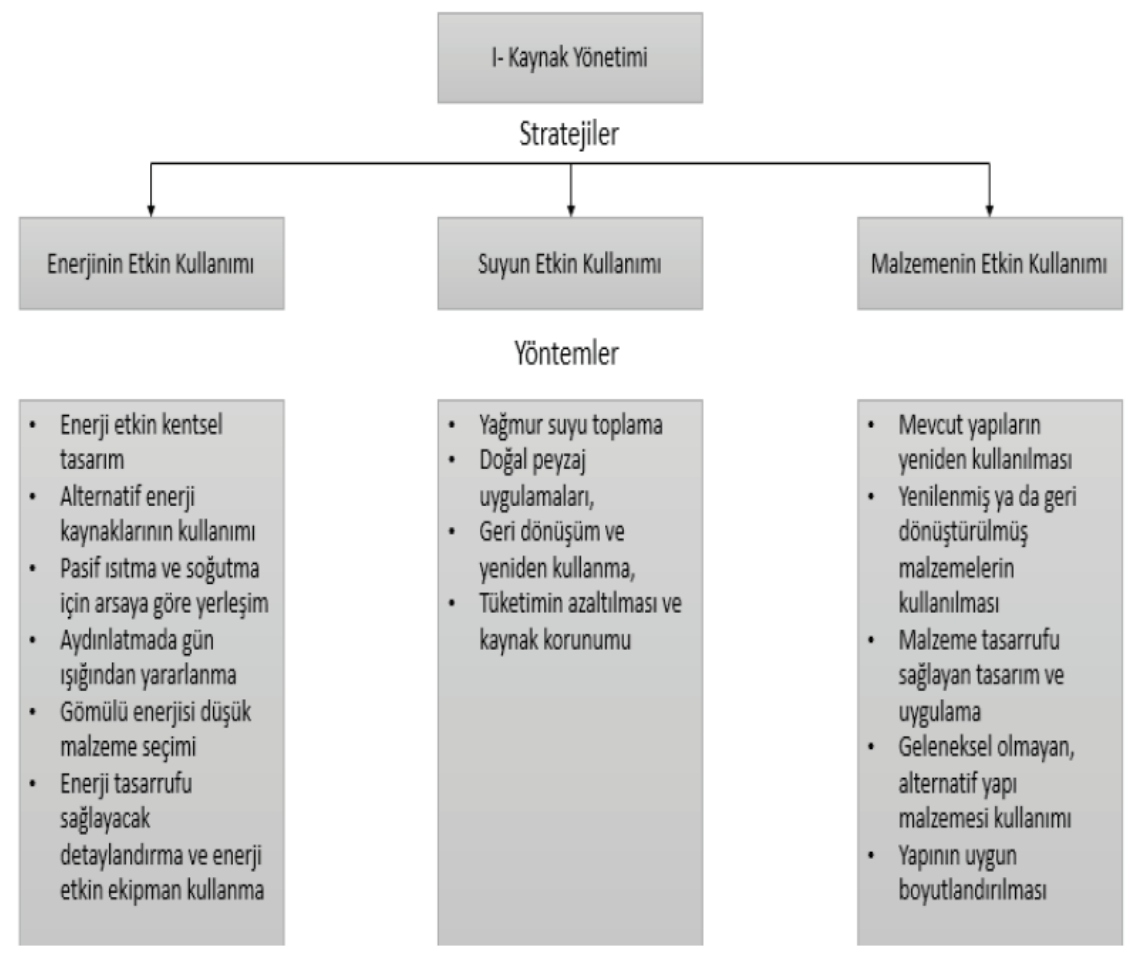

Şekil 2. Kaynak Yönetimi Kapsamında Stratejiler ve Yöntemler [7]

\subsection{Türk milli eğitim sistemi, yükseköğretim kurumları ve üniversiteler}

Yükseköğretim Kurumları, bilim dallarının öğretildiği, araştırıldığ1 ve tartışılıp elde edilen verilerin yayımlandığı bir ortamdır. Bu tanımda belirtilen dört unsurdan birinin eksikliği, o ortamı, üniversite kavramının dışarısında bırakır [9]. Günümüzde üniversite sözcüğü, değişik konularda en yüksek seviyede araştırma ve öğretimin yapıldığı fakülte, yüksekokul ve enstitüleri barındıran, araştırmacıları ödüllendirme ve derecelendirme yetkisine sahip yükseköğretim kurumu anlamındadır. Üniversite sözcük anlamı, aynı zamanda binaları, üyeleri ve çalışanları da içine almaktadır [10]. Kampüs kavramı ise; Orta 
Çă̆'ın Castrum'larından (kamplarından) etkilenerek, bir ortak düzen üzerinde tekrarlanan üniteler ve bunların gelişmesi düşünülerek, temel fikrin bozulmayacağı bir bütün teşkili amacıyla Amerika Birleşik Devletleri'nde ortaya çıkmıştır [11]. Kelime anlamı olarak, "açık alan" ya da "düzlük" anlamında olan "kampüs" sözcüğü, şehir içinde veya dişında, bir yeşil alanda kurulmuş, akademik köy veya akademik ideallerin fiziksel planlamaya yansıması olarak da tanımlanmaktadir [12].

Şekil 3 'te Türk Milli Eğitim Sistemine ait bir diyagram gösterilmektedir. Çalışma kapsamında ele alınacak sürdürülebilir eğitim yapısı örnekleri yükseköğretim yapıları içerisinden seçilecektir. Yükseköğretim kurumlarına ait birimler; üniversiteler, fakülteler, enstitüler, yüksekokullar, konservatuvarlar, Meslek Yüksek Okulları (MYO), Uygulama ve Araştırma Merkezleri olarak sınıflandırılmaktadır [13]. 


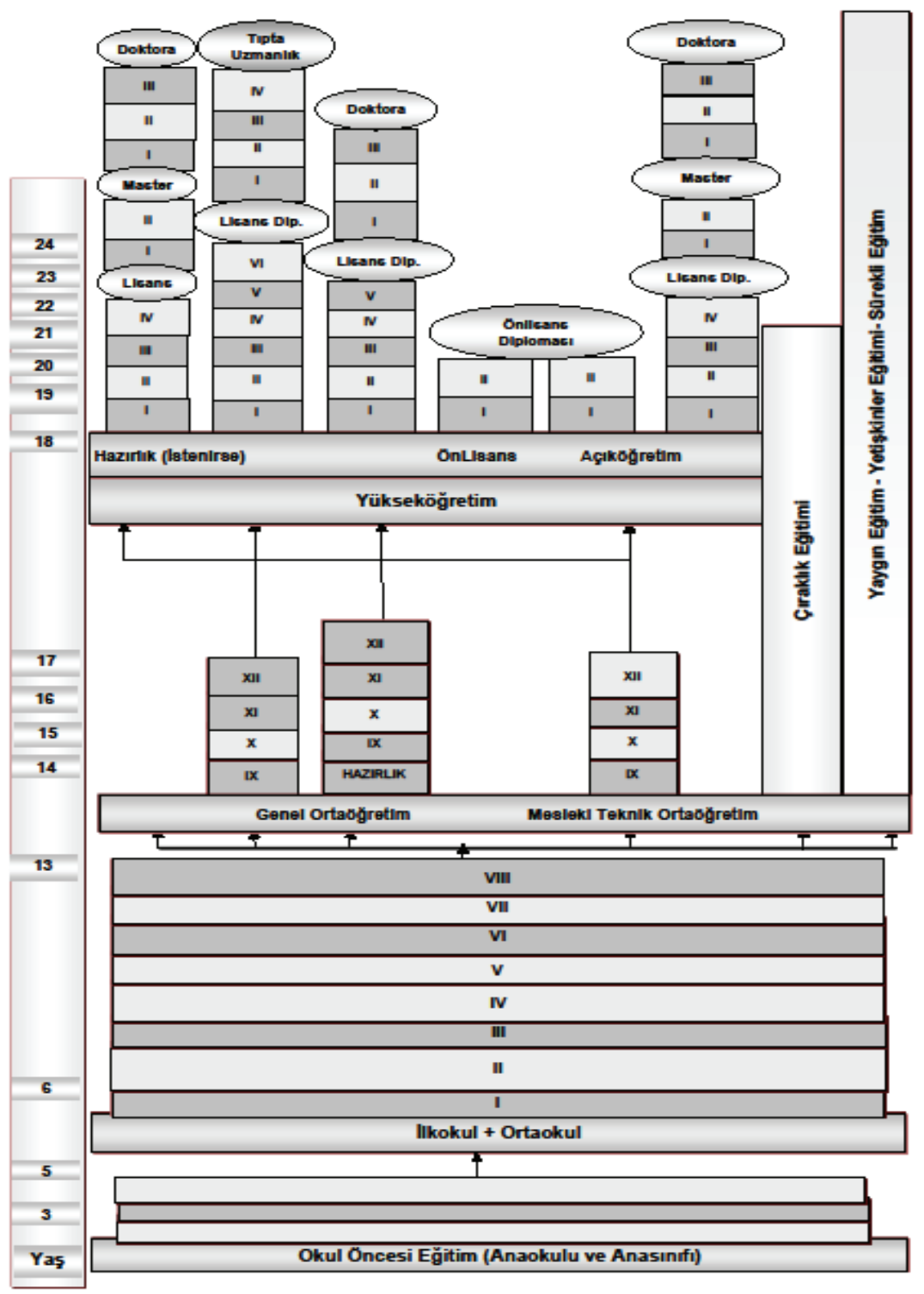

Şekil 3. Türk Milli Eğitim Sistemi [13]

Türkiye'deki 2018-2019 yükseköğretim istatistiklerine göre 129 adet devlet üniversitesi, 73 adet vakıf üniversitesi ve 5 adet vakıf meslek yüksekokulu bulunmakta ve 7.740 .502 öğrenci bu kurumlarda 
eğitim görmektedir [14] (Şekil 4). Yaklaşık 7,5 milyon üniversite öğrencisinin vaktinin büyük bir çoğunluğunu okullarında geçirdiğini düşünürsek bu eğitim yapılarının sürdürülebilir nitelikler taşımasının sürdürülebilirlik bilincinin elde edilmesi ve yerel kalkınma üzerinde yaratacağı faydalar adına önemi yadsınamaz.

Öğrenim Düzeyine Göre Öğrenci Sayısı

$\equiv$

2018-2019 Yükseköğretim İstatistikleri

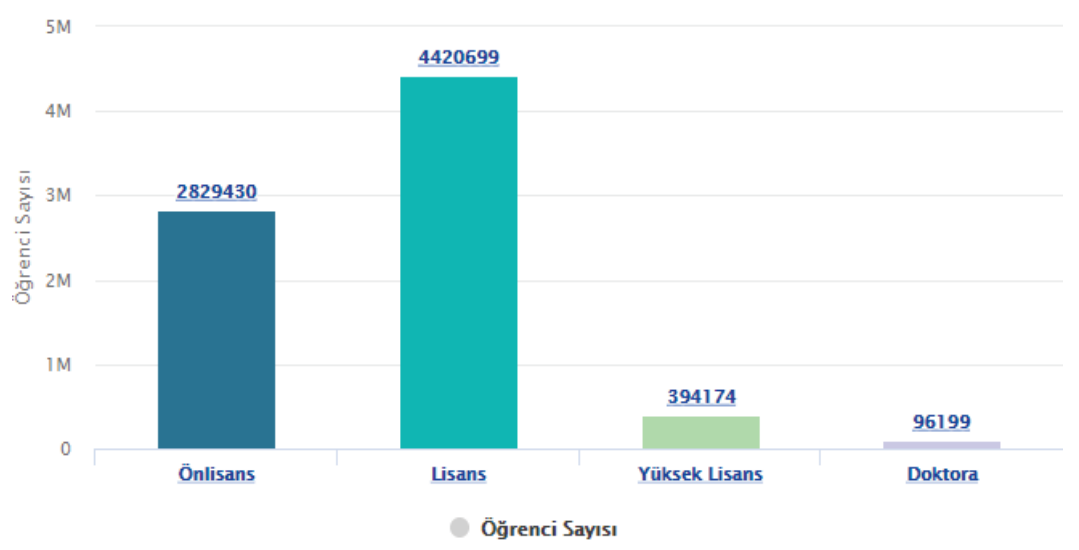

Türlerine Göre Mevcut Üniversite Sayısı

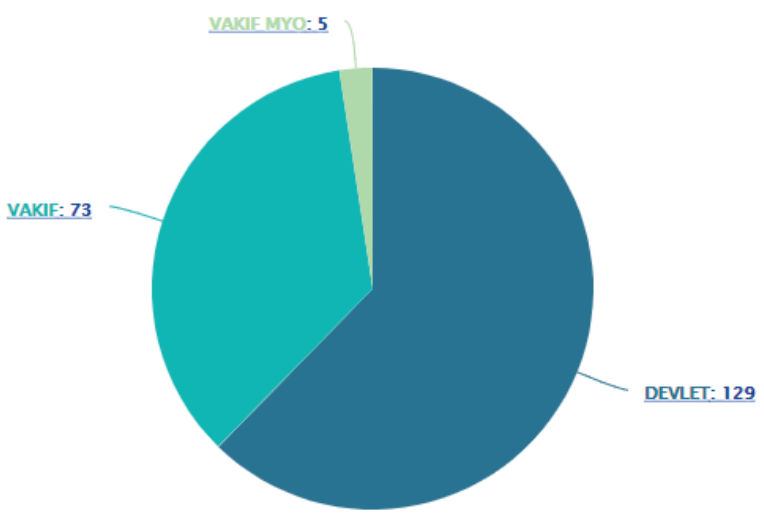

Şekil 4.Türkiye'deki 2017-2018 Yükseköğretim Öğrenci ve Üniversite İstatistikleri [14] 
Yükseköğretim Kurumları, çalışma prensipleri gereği günümüzün bilim ve teknoloji standartlarını kullanmayı ve hep bir üst noktaya ulaşmayı arzu etmektedir. Çağdaş ve yenilikçi yapılarıyla istikrarlı bir üretim modeli arz eden yükseköğretim kurumları sürekli büyüme ve gelişmeyi ilk hedefleri olarak görmektedir [15]. Bu bağlamda yükseköğretim yapılarının da yenilikçi yapım teknolojileri ile inşası kalitenin arttırılması açısından büyük önem arz etmektedir.

\section{Bulgular}

Çalışmada Türkiye'nin farklı şehirlerinde inşa edilmiş, kaynaklarını etkin bir biçimde kullanabilen yükseköğretim kurumlarına yer verilmiştir. Hangi uygulama, tasarım ve teknolojilerle enerjiyi,suyu ve malzemeyi etkin olarak kullanabileceği ele alınmıştır.

\subsection{Yeditepe Üniversitesi (Kayışdağı - İstanbul)}

1996 senesinde İSTEK Vakfı tarafindan kurulan Yeditepe Üniversitesi, İstanbul Kayışdağı'nda 125 bin metrekarelik bir alanda bulunmakta ve 223 bin metrekarelik bir kapalı alana sahiptir (Şekil 5). Selçuklu mimarisinden esinlenen kampüs, sürdürülebilirlik anlayışıyla inşa edilmiştir [16].

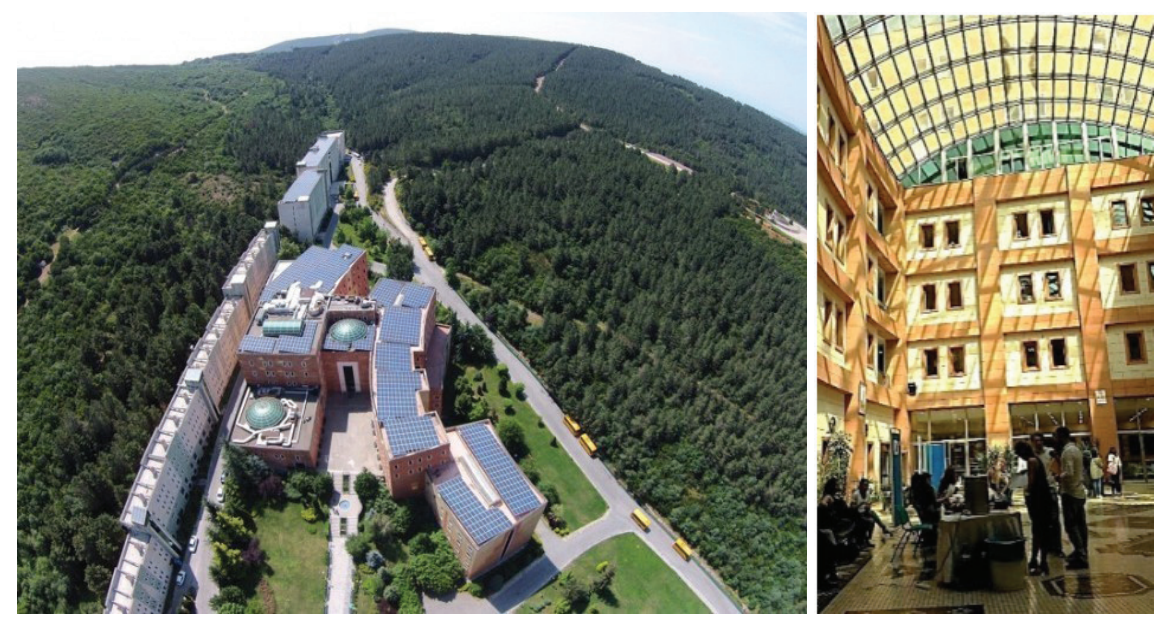

Şekil 5. Yeditepe Üniversitesi [17] 
Yeditepe Üniversitesinde etkin kaynak yönetimi kapsamındaki uygulamalar [17];

- Kendi enerjisini üretebilmek adına çatısında güneş enerji panellerinin bulunmas1,

- Enerji etkinliği adına doğal aydınlatmadan ve havalandırmadan maksimum oranda faydalanabilen avlu sistemine sahip olmas1,

- Malzeme etkinliği adına, dış cephede Anadolu'dan getirilen doğal taşların kullanımı,

- Enerji etkinliği adına dış cephede kullanılan ünye taşının binayı yazın serin, kışın sıcak tutma niteliği,

- Dış cephenin 1sı yalıtımında enerji etkinliği adına poliüretan kullanımı,

- Suyun korunumu ve çevreye verilen zararın minimuma indirilmesi açısından biyolojik atık su tesisinin yapılması,

- Malzemelerin etkin kullanımı için organik ve inorganik atıkların geri dönüşümü,

- Toksik atıkların bertaraf edilmesi,

- Suyun etkin kullanımı için geri dönüşümlü su kullanımı ve su etkin peyzaj düzenlemeleri,

- Binalarda enerji etkin cihazların kullanımı,

- Elektrik tasarrufu elde etmek için sensörlü aydınlatma sistemlerinin kullanımı,

- Islak hacimlerde su etkin ekipman tercihi şeklinde sıralanabilir

\subsection{Uşak Üniversitesi 1 Eylül Kampüsü Merkezi Derslik Bloğu (Kaşbelen -Uşak)}

Uşak Üniversitesi Merkezi Derslik Bloğu yaklaş1k 6000m2'lik kapalı alanı ile Uşak 1 Eylül kampüsünde 2010 senesinde inşa edilmiştir (Şekil 6). 


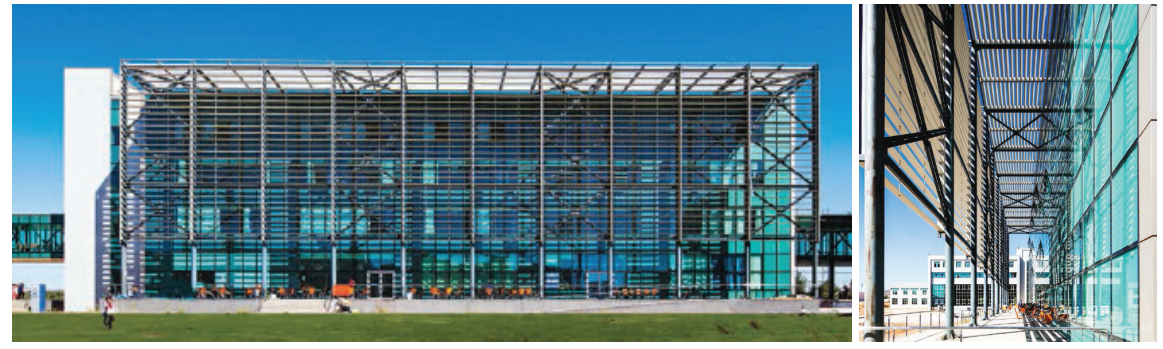

Şekil 6. Uşak Üniversitesi 1 Eylül Kampüsü Merkezi Derslik Bloğu [18]

Binada kaynak etkinliği kapsamında [18];

- Diş cephesinde HVAC sistemlere az yük getirmek ve enerji tasarrufları elde etmek adına yalıtım katsayısı oldukça yüksek özel cam paneller kullanılmıştır.

- Batı yönünde 4 kat yüksekliğinde çift katmanlı bir cepheye sahiptir. Dış kabuktaki açısı değiştirilebilen gün kırıcılar ile güneşin kamaşma ve binayı 1sıtma etkilerinin önüne geçilerek ciddi enerji tasarrufları elde edilmektedir.

- Zemin kat, malzeme etkinliği açısından esnek bir tasarım anlayışıyla her bölümden öğrencinin kullanabileceği ve sosyalleşebileceği bir yapıya sahiptir.

- Çatıyı neredeyse tümüyle kaplayan çatı 1şıklığı sayesinde gün 1şı̆̆ından maksimum fayda sağlanmaktadır. Tasarımdaki merkezi galeri boşluğuyla çatı kotundan alınan gün ışığıyla en alt katlara kadar doğal aydınlatmadan faydalanılabilmektedir.

- Çatı 1şıklığında açılıp kapanabilen camlar sayesinde binanın doğal yollarla havalandırılması sağlanmaktadır.

\subsection{Piri Reis Üniversitesi (Tuzla - İstanbul )}

Tuzla'da kurulan ve denizcilik üzerine eğitim veren Piri Reis Üniversitesi, 60.000m2'lik bir alanda 8 bloktan oluşmaktadır (Şekil 7). İngiliz sertifika sistemi BREEAM'in "very good” derecesine sahip olan üniversite, sürdürülebilir tasarım ilkelerini benimseyerek inşa edilmiştir [19]. 

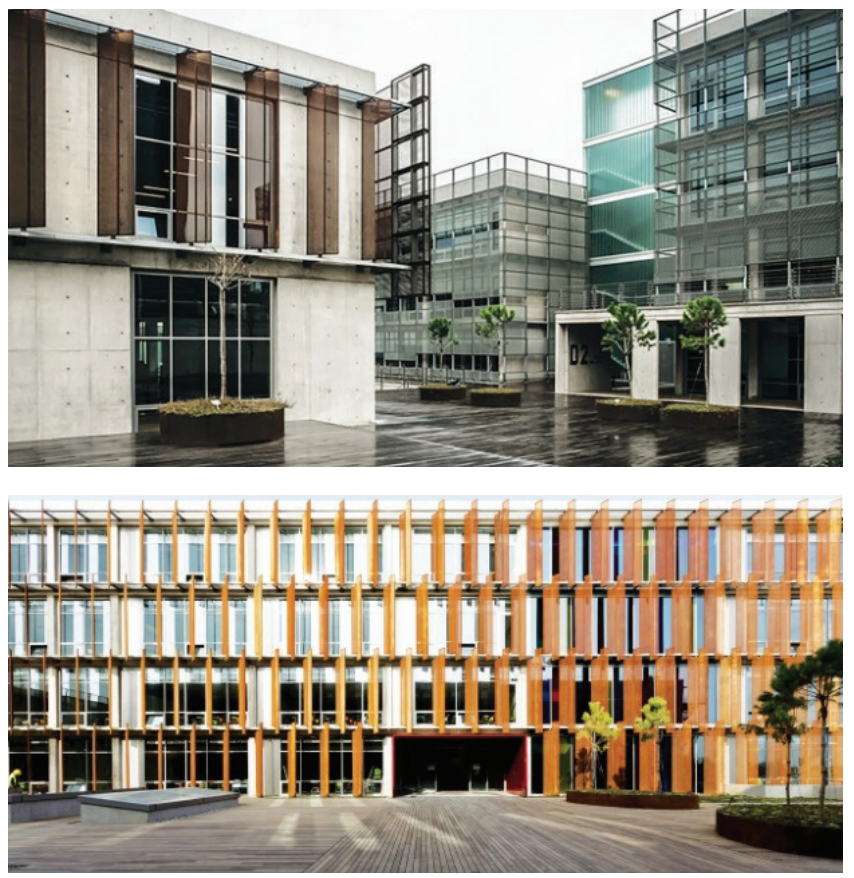

Şekil 7. Piri Reis Üniversitesi [20]

Piri Reis Üniversitesinde etkin kaynak yönetimi kapsamındaki uygulamalar [20];

- Sahip olduğu trijenerasyon sistemi ile kampüsün elektrik ihtiyacının \%45'inin, soğutma-1sıtma ihtiyacının \%50'sinin karşılanmas1,

- Suyun etkin kullanımı adına deniz suyunun tatlı su kaynağına dönüştürülmesi ve bu suyun ıslak hacimlerde, yangın su depolarında ve trijenarasyon merkezinde kullanımı,

- Yağmur ve gri suların rezervuarlarda ve peyzaj sulamasında tekrar kullanımı,

- Otomasyon sistemi ile aydınlatma, 1sitma-soğutma ve elektriğe müdahale ederek ciddi enerji tasarrufları sağlama,

- Tasarımda blokların denize paralel konumuyla hâkim rüzgârın etkisinin hafifletilerek iç bahçeler yaratılması ve gün ışığından maksimum fayda sağlanılması, 
- Güneş panelleriyle elektrik üretimi ve üretilen enerjinin yap1larda kullanımı,

- Çevre düzenlemesinin asgari su ihtiyacını karşılayacak şekilde tasarlanmasi

şeklinde sıralanabilir.

\subsection{Namık Kemal Üniversitesi Tıp Fakültesi Morfoloji Binası (Değirmenaltı-Tekirdağ)}

Tekirdağ çevreyolu üzerinde Değirmenaltı bölgesinde yer alan Morfoloji Binası kampüsün simge yapılarından birini oluşturmaktadır (Şekil 8).

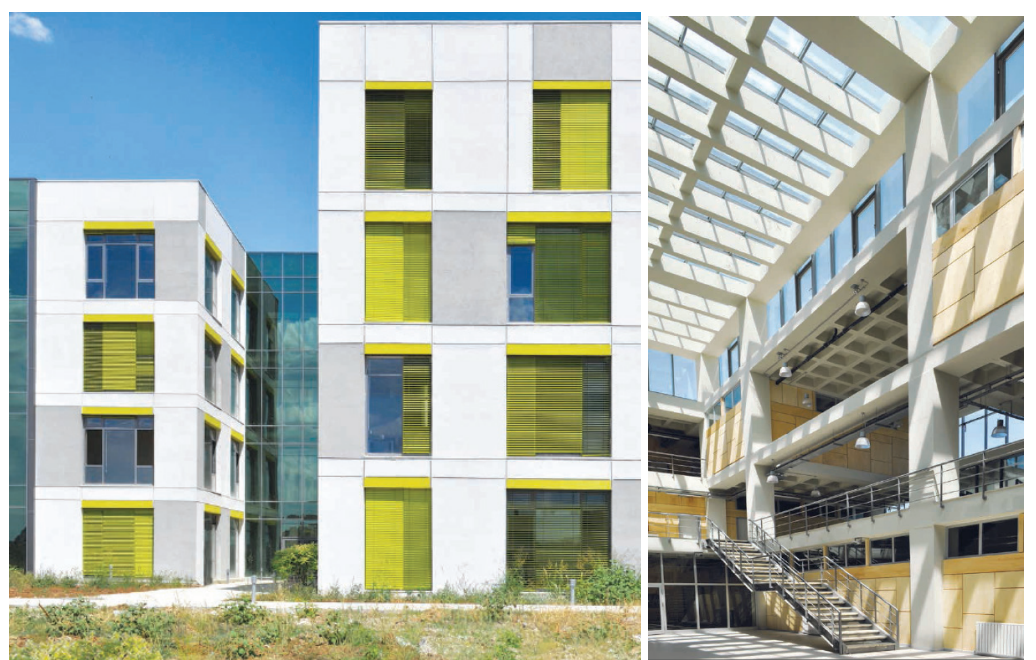

Şekil 8. Namık Kemal Üniversitesi Tıp Fakültesi Morfoloji Binası [18]

Kısıtlı yatırım bütçesi içinde gerçekleştirilen projede etkin kaynak yönetimi kapsamında [18];

- Pasif iklimlendirme sistemleri ile işletme giderleri azaltılmıştır.

- Çatı 1şıklıkları, galeri boşlukları ve şeffaf koridor tasarımı ile gün ışığından faydalanılarak mekanik aydınlatma yerine doğal aydınlatmadan maksimum düzeyde faydalanılmaktadır. 
- Çatıdaki açılabilir pencereler sayesinde mekânın iç hava kalitesi arttırılmakta ve pasif havalandırma sağlanarak sıcak vakitlerde binanın soğutma yükü azaltılmaktadır.

- Cephe tasarımında etkin ve yalın malzeme kullanımı ile modern bir cephe algısı yaratılmıştır.

- Strüktür ve teknik donanım net bir şekilde açıkta bırakılarak mekânların daha anlaşılır ve ayrıştırılabilir olması sağlanmıştır.

- Bölücü duvarlarda ahşap kaplı doğal malzemeler tercih edilmiştir.

\section{5. Özyeğin Üniversitesi Mühendislik Fakültesi ve Öğrenci Merkezi (Çekmeköy-İstanbul)}

Özyeğin Üniversitesi Çekmeköy Kampüsü toplamda 280 bin metrekare alanda kurulu bir yerleşkedir [21]. Kampüs kapsamında Mühendislik Fakültesi ve Öğrenci Merkezi LEED Gold sertifikasına sahiptir (Şekil 9).
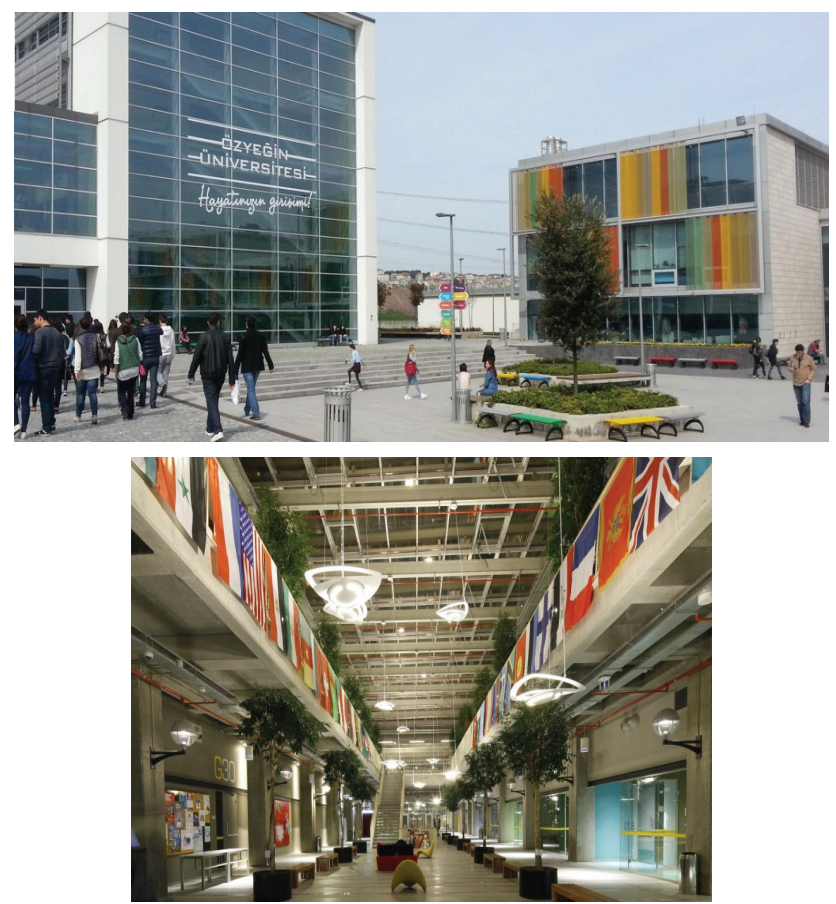

Şekil 9. Özyeğin Üniversitesi Mühendislik Fakültesi ve Öğrenci Merkezi [22] 
Özyeğin Üniversitesinde etkin kaynak yönetimi kapsamındaki uygulamalar [22];

- Binada her türlü sistemin enerji sarfiyatları enerji analizörleri ve bina otomasyon sistemi vasitasiyla gözlemlenmektedir. Bu sayede enerji etkinliğinin hedeflerinin ne ölçüde yakalandığı takip edilebilmektedir.

- Malzemenin etkin kullanımı açısında inşaat esnasında oluşan atıkların, atık yönetim planı ile geri dönüşümü sağlanmıştır. Ayrıca bina kullanımında oluşacak geri dönüştürülebilir atıkların toplanması için yeterli alanlar ayrılmıştır.

- Projenin peyzaj alanlarında az su tüketen ve endemik bitki türleri kullanılmıştır, böylelikle su tüketimi en az seviyeye indirilmiştir. Ayrıca kimyasal gübre kullanımı azaltılarak yer altı sularının kirlenmesi önlenmiştir.

- Mevcut altyapıya getirilen yükün azaltılması için projede sert zemin oranı olabildiğince azaltılmış ve geçirgen yüzeyler arttırılmıştır. Böylelikle yapılaşmaya bağlı su döngünü hasarları hafifletilmiştir.

- Kampüs çevresinde toplu taşıma imkânları yaratılarak bireysel araç kullanımının en az seviyede tutulması hedeflenmiştir. Çevre ile dost alternatif ulaşım olanaklarının sağlanması için bisiklet parkları, hibrit teknolojili araçlara park alanları ve duş imkânları sunulmuştur. Böylelikle ciddi enerji tasarrufları elde edileceği öngörülmüştür.

- Suyun etkin kullanımı adına binadaki gri sular arıtılarak rezervuarlarda değerlendirilmekte ve su tasarruflu armatür-vitrifiyeler kullanılmaktadır.

- Projede kullanılan inşaat malzemelerinin yaklaşık \%20 kadarının geri dönüştürülmüş malzemelerden seçilmesine ve yerel olmasına özen gösterilmiştir.

- Proje kapsamında, soğutma sistemlerinde, çevre dostu soğutucu akışkanlar tercih edilmiştir. 
- Bina tasarımında, gün 1şı̆̆ından en üst düzeyde faydalanılması esas alınmıştır. Bu sayede hem aydınlatmaya harcanan enerjinin azaltılması, hem de gün ışığının iç mekânlarda çalışanların üzerindeki olumlu etkilerinin kullanılması hedeflenmiştir.

- İç mekân termal konfor tasarımı, ASHRAE 55 standardına uygun olarak yapılmıştır. Isıtma ve aydınlatma sistemlerinde bireysel kontrole önem verilerek, hem enerji tasarrufu ve hem de iç yaşam kalitesinin arttırılması hedeflenmiştir. Ayrıca bina içerisine verilen taze hava oranları ASHRAE 62.1 standardının \%30 kadar üzerinde tutulmuştur.

\subsection{Uludağ Üniversitesi Devlet Konservatuvarı (Görükle, Bursa)}

Uludağ Üniversitesi Devlet Konservatuvarı Görükle Yerleşkesinin en batı ucunda eğimli bir araziye oturtulmuş dikdörtgen bir kutu formundadır (Şekil 10). Eğim sayesinde binaya farklı kotlardan girmek mümkün kılınmıştır [23].

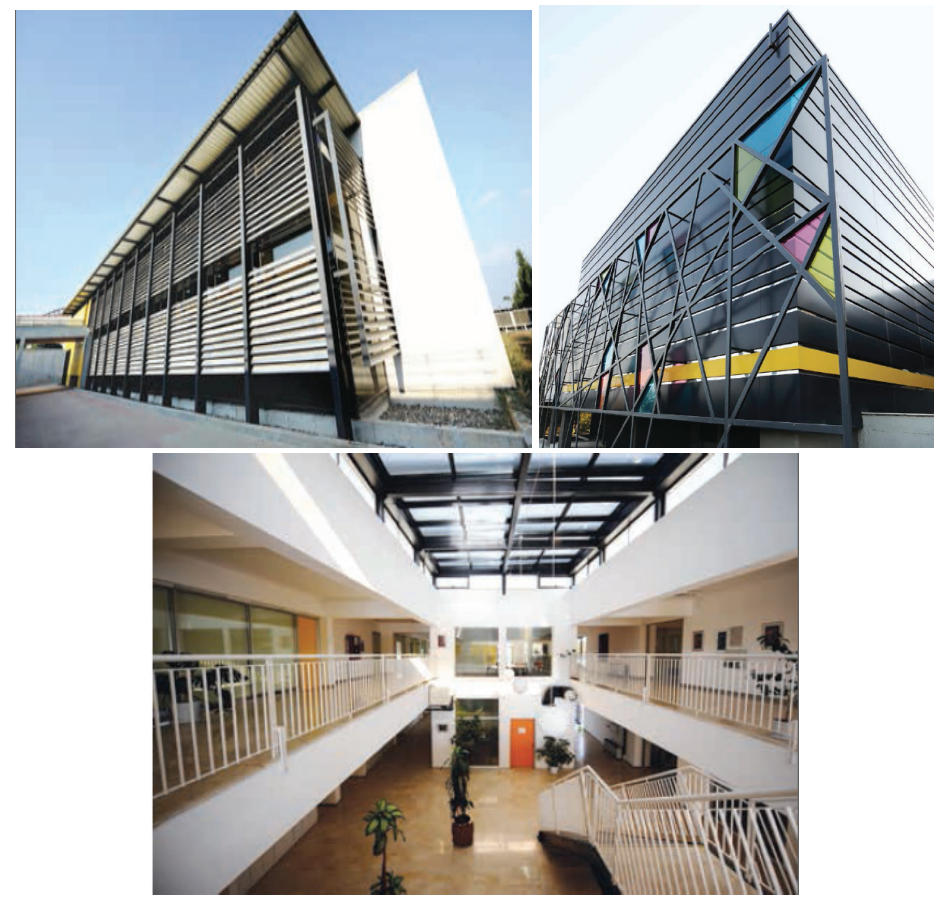

Şekil 10. Uludağ Üniversitesi Devlet Konservatuvar1 [18;23] 
Sınırlı bütçe ile gerçekleştirilen bu binada etkin kaynak yönetimi adina [18];

- Çatı 1şıklıklarından gün ışığı alınarak doğal aydınlatmadan faydalanılmıştır.

- Yapının iç tasarımı galeriler, köprüler, sokaklar ve tepe 1şıklıklarıyla süreklilik göstermektedir.

- Mekânlar dönüşebilmeye ve performans sergilenmeye? müsait alanlardir.

- Yalın, az ve öz malzeme kullanımıyla ilgiyi kendi üzerine çekmekten çok icra edilen sanata yöneltir.

- Galerili yapısıyla çatı 1şıklığından gelen doğal 1şığın alt katlara ulaşması sağlanılır. Böylelikle yapay aydınlatma ihtiyacında ciddi bir düşüş gözlenir.

- Çatı 1şıklıklarındaki açılıp kapanabilen pencereler sayesinde pasif havalandırma mümkün olmakta ve mekânın iç hava kalitesi arttırılabilmektedir.

- Ekonomik malzeme kullanımı ve aşırılığa kaçmayan bir tasarım anlayışıyla yalın ama fark edilebilir bir örüntü oluşturulmuştur.

\subsection{TOBB Ekonomi ve Teknoloji Üniversitesi Öğrenci Konukevi Yapıları (Söğütözü-Ankara)}

Türkiye Odalar ve Borsalar Birliği Ekonomi ve Teknoloji Üniversitesinin Söğütözü Yerleşkesinde yer alan öğrenci konukevi yapıları 2007 senesinde yerleşkenin gelişme planları doğrultusunda hayata geçirilmiştir (Şekil 11) [24]. 


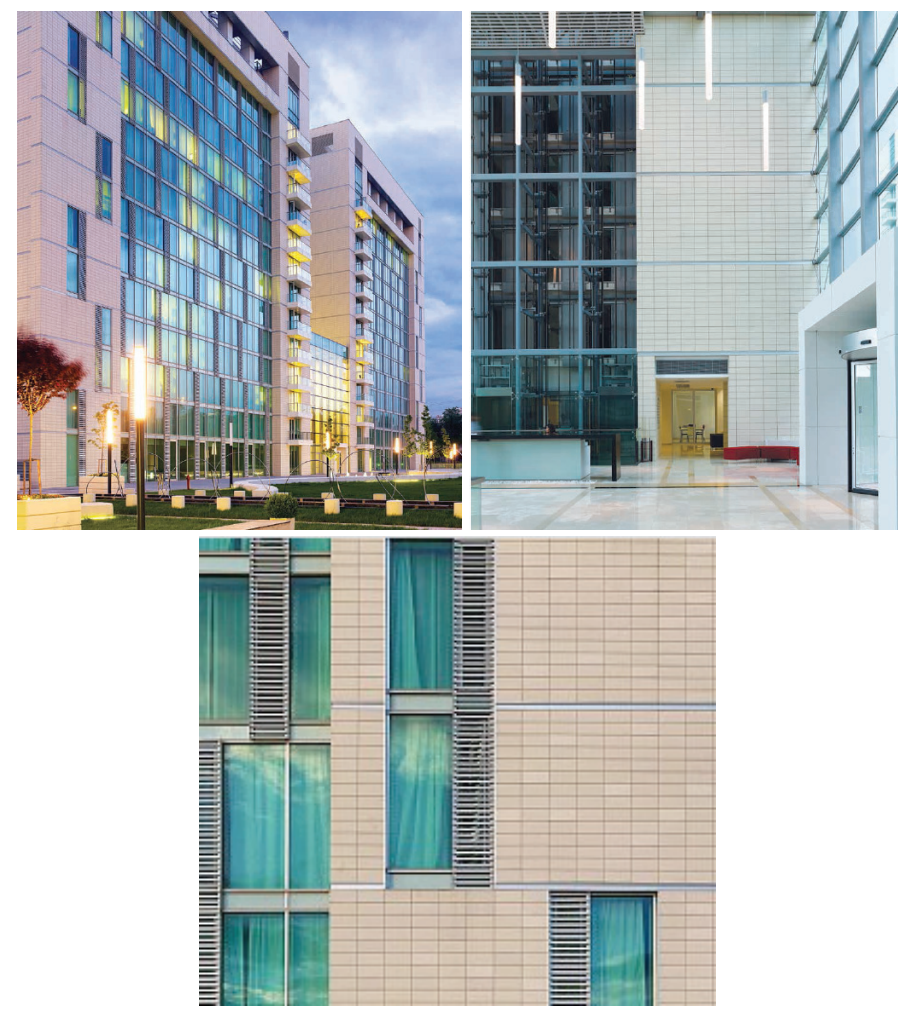

Şekil 11. TOBB Ekonomi ve Teknoloji Üniversitesi Öğrenci Konukevi Yapıları [18]

Kaynakların etkin kullanımı adına [18;24];

- Tünel kalıp taşıyıcı sistem ile yapının hızlı inşa edilmesi sağlanmış ve esnek kullanıma uygun değişebililir-dönüşebilir mekânlar yaratılmıştır.

- Giydirme cephe sistemi sayesinde hacimlerde şeffaflık elde edilmiş ve gün 1şığından olabildiğince faydalanılarak binanın yapay aydınlatma yükü azaltılmıştır.

- Cehpenin opak kısımlarında doğal malzeme olan tuğlalar tercih edilmiştir.

- Cephe tasarımında açılır kanat önüne eklenen menfez panelleri sayesinde taze hava içeri alınabilmekte ve içerideki kirli hava 
tahliye edilebilmektedir. Ayrıca yüksek katlarda güvenlik gerekçesi ile bu paneller cephenin bir eklentisi olarak doğal havalandırmayı mümkün kılmaktadır.

- Engelli öğrencilere ait özel odalar alt katlarda tasarlanarak eğitim eşitliği adına sosyal bir farkındalık yaratılmıştır.

- Öncesinde ortaöğretim kurumu olarak kullanılan yapılara yıkım kararı verilmemiş ve yeniden değerlendirilerek bir yükseköğretim yerleşkesi oluşturulmuştur. Mevcut strüktür rehabilitasyonu sayesinde malzemeden etkin olarak faydalanılmıştır.

\subsection{Sabancı Üniversitesi Nanoteknoloji Araştırma ve Uygulama Merkezi (SUNUM) (Tuzla, İstanbul)}

SUNUM binası, T.C. Kalkınma Bakanlığı ve Sabancı Vakfının katk1ları ile 65 milyon TL yatırımla kurulmuş 7500 m2'lik çevre dostu bir araştırma merkezidir (Şekil 12). Türkiye'nin ilk BREEAM Very Good ve LEED Gold sertifikasına sahip binasıdır [25].

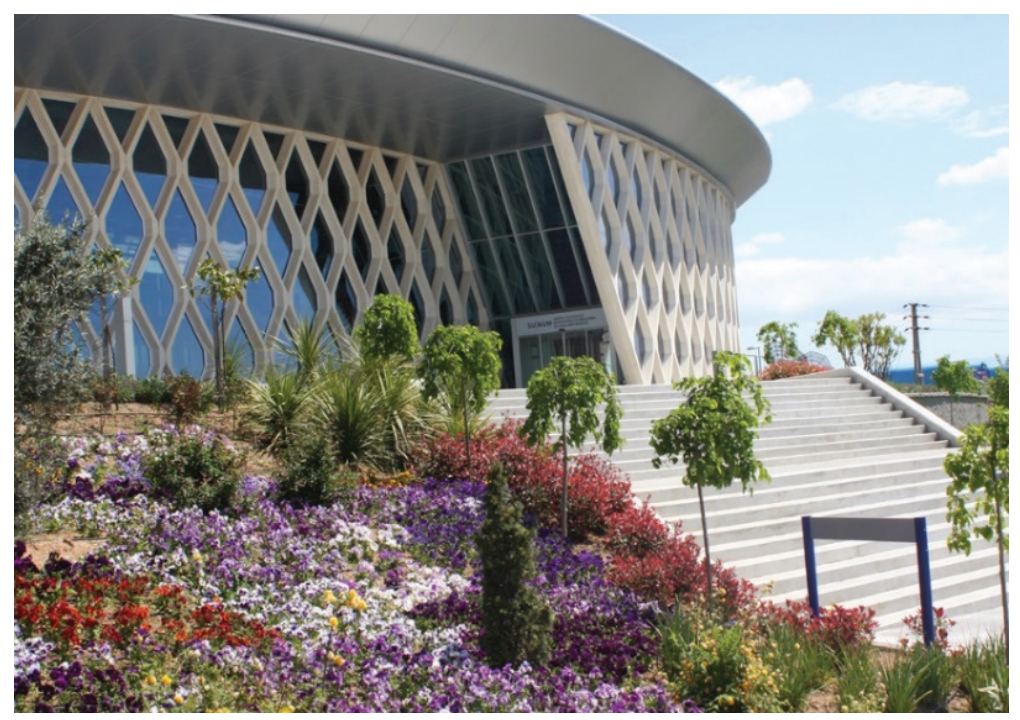

Şekil 12. SUNUM Binas1 [25] 
Etkin kaynak yönetimi kapsamında [25;26];

- Binanın HVAC, aydınlatma ve diğer sistemleri ASHRAE 90.12007 enerji etkinliği standartlarına uygundur. Böylelikle diğer klasik binalara oranla \%25 daha az enerji tüketilmektedir.

- Enerji tasarruflu ve iç hava kalitesini yükselten değişken hava debili havalandirma sistemlerine sahiptir.

- Malzeme etkinliği kapsamında çevre dostu, geri dönüşümlü malzemeler tercih edilmiş ve inşaat esnasında atık üretimi minimumda tutulmuştur.

- Su etkinliği kapsamında yağmur suyu değerlendirilmiş, su tasarruflu armatürler kullanılmış ve su etkin peyzaj düzenlemeleri gerçekleştirilmiştir.

- Bina her ihtiyaca cevap verebilen ve malzeme etkinliği adına istendiğinde küçülüp büyüyebilen esnek bir tasarıma sahiptir.

- Gelişmiş aydınlatma kontrol sistemi ve enerji etkin aydınlatma ekipmanlarına sahiptir.

- Çatıdaki güneş panelleri ile sıcak su elde edilmekte ve aynı zamanda klima santrali için soğutulan havanın tekrardan 1sıtılması sağlanmaktadır.

- Diş cephede low-e kaplamalı, argon gaz dolgulu yalıtımlı camlar ve C-60 yapısını temsil eden dış kabuk kullanılarak enerji tüketiminde? ciddi 1 sı tasarrufları elde edilmektedir.

\section{9. İzmir Ekonomi Üniversitesi Güzel Sanatlar ve Tasarım Fakültesi (Balçova - İzmir)}

2004 senesinde kurulan Güzel Sanatlar ve Tasarım Fakültesi, Balçova kampüsü içerisindeki yeni binasında eğitim-öğretime 2010 senesinde başlamıştır (Şekil 13). 


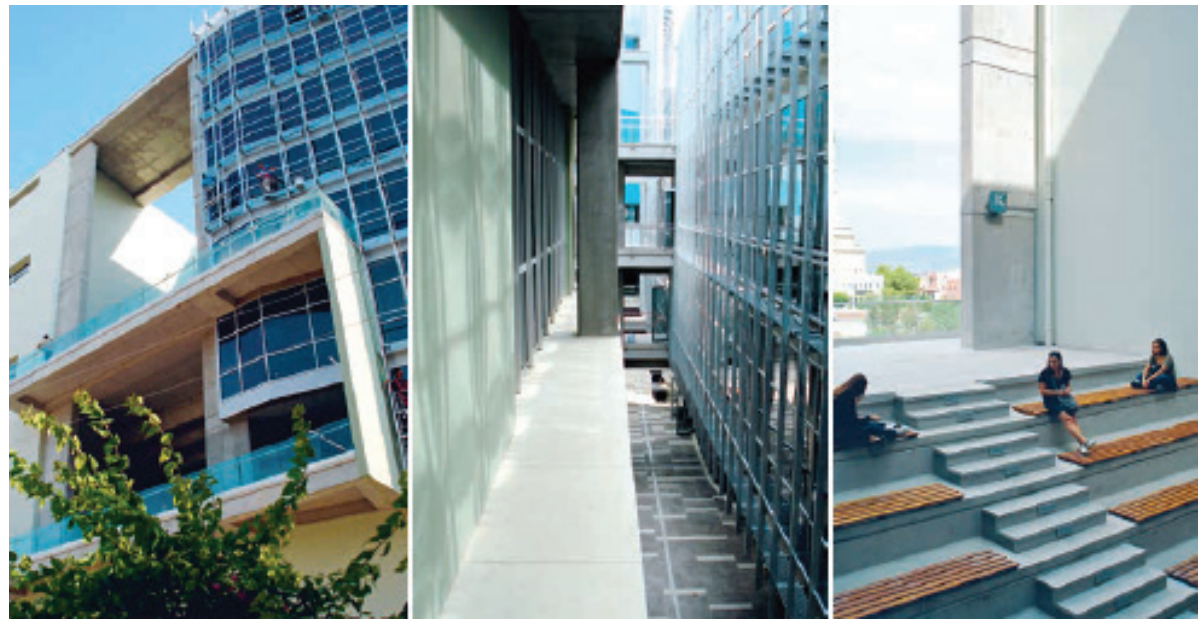

Şekil 13. İzmir Ekonomi Üniversitesi Güzel Sanatlar ve Tasarım Fakültesi [18]

Fakülte Binası kaynak etkinliği kapsamında [18];

- Kullanılmayan bir otel kompleksinin yeniden işlevlendirilmesiyle meydana gelmiștir. Fakülte binası hâlihazırda bulunan yer altı otoparkının aksları üzerine oturtularak malzemenin etkin kullanımı sağlanmıştır.

- Binada bütünleşik tasarım anlayışı ile farklı disiplinlerin bir arada olabileceği ve faydalanabileceği sürdürülebilir bir yaklaşım sergilenmiştir.

- Malzeme tercihinde doğal ve geri dönüşümlü malzemeler kullanılmıştır.

- Cam ve brüt betondan oluşan diş kabuk ile yalın ve şeffaf bir etki yaratılmıştır. Bu geçirgen yapı sayesinde gün ışığından maksimum oranda faydalanılmıştır.

- Binadaki esnek tasarım anlayışı ile eğitim stüdyolara hapsolmamıştır. Dersliklerin açıldığı orta holler birer etkileşim ve kesişim alanlarına dönüşmüştür.

- Binadaki açık iç avlu yarı meydansı bir sokak görünümünde tüm tasarım ürünlerinin sergilendiği bir mekâna dönüşebilecek bir yapıya sahiptir. 


\section{Tartışma}

Kaynaklarını etkin kullanabilen eğitim yapılarında öğrenim gören öğrencilerin bu konuda ne kadar bilince sahip olduğu belirsiz bir konu olarak karşımıza çıkmaktadır. Çalışma kapsamında ele alınan yükseköğretim yapılarında öğrenim gören öğrencilerle yapılan görüşmeler sonucunda bazılarının, binaların kaynak etkinliğiyle ilgili yeterli bilgi ve donanıma sahip olduğu bazılarının ise binaların özellikleriyle ilgili hiçbir fikri olmadığı görülmüştür. Bu bağlamda öğrencilerde sürdürülebilir kalkınma bilincini geliştirmek adına eğitim binalarının belirli yerlerine sürdürülebilir nitelikleriyle ilgili bilgilendirme tabelaları koymanın büyük bir farkındalık yaratacağı öngörülmektedir. Ayrıca öğrencilerin ders müfredatlarına ekoloji ile ilgili seçmeli derslerin eklenmesi, seminerlerin düzenlenmesi ve öğrenci katılımının sağlanması sürdürülebilir kalkınma bilincinin oluşturulması adına büyük önem taşımaktadır.

\section{Sonuçlar}

Yakın geçmişte birçok yükseköğretim yerleşkesi veya yapısı geleneksel yöntemlerle inşa edilmekteydi. Sanayi devrimiyle ortaya ç1kan ve akabinde küreselleşme ile etkilerini çok baskın bir şekilde hissettiren doğal kaynak krizleri sonucunda sürdürülebilir teknolojiler benimsenmeye başlanmıştır. Sürdürülebilirlik konusu, yükseköğretim kurumlarının ideolojik ve fiziksel yapısı ile birlikte kullanıc1ların da bu konuda sürece dâhil edilmesi şeklinde hayata geçirilmek istenmiştir. Genç bir nüfusa sahip olan Türkiye'de, iyi bir eğitim ortamının oluşturulması için kaynakların etkin kullanımının önemi büyüktür. Toplumun geleceğini oluşturan öğrencilerin, bu konuda bilinçlendirilmesi ve kaynaklarını etkin kullanabilen binalarda eğitim görmeleri büyük önem taşımaktadır. Yapılarda etkin kaynak yönetimi; içinde bulunduğu koşullarda ve varlığının her döneminde, gelecek nesilleri de dikkate alarak, yenilenebilir enerji kaynaklarının 
kullanımına öncelik veren, çevreye duyarlı, enerjinin, suyun, malzemenin ve bulunduğu alanın etkin bir şekilde kullanılmasıyla mümkün olan bir yönetim biçimidir.

Çalışmada Türkiye'nin farklı şehirlerinde bulunan dokuz yükseköğretim yapısı ele alınmıştır. Bu yapılar; Yeditepe Üniversitesi, Uşak Üniversitesi 1 Eylül Kampüsü Merkezi Derslik Bloğu, Piri Reis Üniversitesi, Namık Kemal Üniversitesi Tıp Fakültesi Morfoloji Binası, Özyeğin Üniversitesi Mühendislik Fakültesi ve Öğrenci Merkezi, Uludağ Üniversitesi Devlet Konservatuvarı, TOBB Ekonomi ve Teknoloji Üniversitesi Öğrenci Konukevi Yapıları, Sabancı Üniversitesi Nanoteknoloji Araştırma ve Uygulama Merkezi ve İzmir Ekonomi Üniversitesi Güzel Sanatlar ve Tasarım Fakültesidir. Bu yükseköğretim yapılarında etkin kaynak yönetimi kapsamında aşağıdaki yöntemlerin uygulandığı görülmüştür. Bunlar;

- Fotovoltaik panel kullanımı ile güneş enerjisinden yararlanılması ve binanın enerji ihtiyacının bir bölümünün bu panellerden sağlanması (Enerji Etkinliği),

- Gri su şebekesi denilen sistemle atık suların arıtılıp tekrardan binanın rezervuarlarında, çevre temizliğinde veya peyzaj sulamasında kullanımı (Su Etkinliği),

- İnsan sağlığına zarar veren kimyasallar içermeyen, doğal malzeme kullanımı (Malzeme Etkinliği),

- Yapıların kapasite ve ihtiyaçları doğrultusunda uygun boyut ve formların oluşturulması (Malzeme Etkinliği),

- Yağmur sularının toplanıp binanın rezervuarlarında, çevre temizliğinde veya peyzaj sulamasında kullanımı (Su Etkinliği),

- Esnek tasarıma uygun, değişebilir, dönüşebilir mekânların tasarımı (Malzeme Etkinliği),

- Enerji etkin cephe tasarımıyla binanın enerji ihtiyaçlarının düşürülmesi (Enerji Etkinliği),

- Islak hacimlerde su etkin ekipmanlar kullanılarak ciddi su tasarruflarının sağlanması (Su etkinliği), 
- Cephelerdeki gün kırıcılarla güneşin binayı 1sıtma yüklerinin azaltılması (Enerji Etkinliği),

- Cephedeki uygun boyutta açılmış açıklıklar sayesinde gün 1ş1ğından maksimum fayda sağlanılması ve yapay aydınlatma yükünün azaltılması (Enerji Etkinliği),

- Çatı 1şıklıkları sayesinde gün 1şığından ve doğal aydınlatmadan faydalanılması (Enerji Etkinliği),

- Çatı 1şıklıklarındaki açılıp kapanabilir pencereler ile binanın taze hava ihtiyacının sağlanması ve doğal havalandırma ile soğutma yüklerinin azaltılması (Enerji Etkinliği),

- Bina otomasyon sistemi ile enerjinin ve suyun ölçümünün yapılması ve gerektiğinde müdahale edilmesi (Enerji-Su Etkinliği),

- Arazinin topografik yapısını bozacak müdahalelerden kaçınma ve uygun yerleşim (Malzeme Etkinliği),

- Şantiye aşamasında sürdürülebilir atık yönetiminin gerçekleştirilmesi (Malzeme Etkinliği),

- Yeşil çatı ve düşey bahçe tasarımlarıyla 1sı kaçışlarının önüne geçilmesi ve suyun korunumunun sağlanması (Enerji-Su Etkinliği),

- Yeşil alan tasarımlarında endemik bitki örtüsü ve/veya az bakım-su isteyen peyzaj seçimi (Suyun Etkinliği),

- Doğal, yöreye özgü, gömülü enerjisi düşük yerel malzeme seçimi (Malzeme Etkinliği),

- Geri dönüşümlü malzeme tercihi (Malzeme Etkinliği),

- Su ve 1sı izolasyon uygulamaları ile ciddi tasarrufların elde edilmesi (Enerji-Su Etkinliği).

Sonuç olarak kaynaklarını etkin kullanabilen yapılar inşa etmek çevresel, sosyal ve ekonomik kalkınma adına ciddi yararlar sağlayacaktır. Yükseköğretim yapılarında kaynakları etkin kullanabilen teknolojilerin uygulanması, bu kurumlarda eğitim-öğretim gören genç nüfusta farkındalık yaratmak adına büyük önem taşımaktadır. 
Türkiye'de sürdürülebilir eğitim yapılarının her geçen gün artış gösterdiği bir gerçektir fakat bu oran dünya ile kıyaslandığında halen istenilen düzeyde değildir. Devlet politikalarında, ilgili yasa ve yönetmeliklerde yapılarda kaynakların etkin kullanımı adına bazı yaptırımların olması gereklidir. Kaynaklarını etkin kullanabilen yükseköğretim kurumlarına devlet teşvikleri sağlanmalı ve bu konuyla ilgili kamu spotları yürütülmelidir.

\section{Teşekkür}

Yüksek Mimar Melisa Uygun Ugutmen olarak Haliç Üniversitesi Mimarlık Anabilim Dalında yüksek lisans tez danışmanım olan Dr.Öğr. Üyesi Gözde ÇAKIR KIASIF'a çalışmanın kurgu, planlama, kaynak tarama ve kaleme alma aşamalarındaki desteklerinden dolayı saygılarımı sunarım. Daha öncesinde bu alandaki kendi yapmış olduğu çalışmaları, elindeki tüm kaynakları benimle paylaştığı ve tezimdeki eksiklikleri bu makale ile biraz olsun kapatabilme firsatını bana sağladığ için teşekkürü kendisine bir borç bilirim.

\section{Kaynaklar}

[1] Çakır Kıasıf, G., Enerji Etkin Çift Kabuk Cephe Sistemlerinde Yangın Performansını İyileştirecek Yöntemler, 8. Ulusal Çatı \& Cephe Sempozyumu (s.293299), 2- 3 Haziran 2016 Mimar Sinan Güzel Sanatlar Üniversitesi Fındıklı- İstanbul.

[2] Müller, D. G., Sustainable Architecture and Urbanism: Concepts, Technologies, Examples, Birkhauser, Basel·Berlin·Boston, 2002.

[3] Çakır Kıasıf, G., Sürdürülebilir Yükseköğretim Yapıları: İstanbul'daki sürdürülebilir yükseköğretim yapılarının LEED kriterleri kapsamında karşılaştırmalı analizi, Yapı Dergisi, Say1:448, Haziran 2019,ss.30-39.

[4] Martin, M., Chestnut Hill -A Sustainable Community Profile [Roots], Places, 9(3), p.30-37, 1995.

[5] Gilman, R., Sustainability By Robert Gilman from the 1992 UIA/AIA Call for sustainable community solutions, 1992. (http://www.context.org)

[6] Yılmaz, M., Mimarlık ve Çevre, Çevre ve Politika, İmge Kitabevi Yayınları, Ankara, 2007. 
[7] Sev, A., Sürdürülebilir Mimarlık, 1. Baskı. İstanbul, Türkiye: YEM Yayın, 2009.

[8] Baysan, O., Sürdürülebilirlik Kavramı ve Mimarlıkta Tasarıma Yansıması, Yüksek Lisans Tezi, İ.T.Ü. Fen Bilimleri Enstitüsü, 2003.

[9] Derman, U., Akademik Standartlara Saygılı Bir Üniversite Yaratmanın Koşulları, Yüksek Öğretimdeki Sorunlar ve Çözümler, Cem Yayınları, İstanbul, 1990.

[10] Ak, S., Üniversite kampüslerinde tasarım kriterlerinin ve yerleşim sistemlerinin büyüme ve gelişme olanakları bağlamında değerlendirilmesi, Yıldız Teknik Üniversitesi, Fen Bilimleri Enstitüsü, 2007.

[11] Aydemir, I.,Üniversite Planlaması ve Mimarisi, Yeterlilik Çalısması, Y.T.Ü İstanbul, 1975.

[12] Turner, P. V., Campus An American Planning Tradition, The MIT Pres Cambridge, Massachusets and London, 1995.

[13] Anonim, Milli Eğitim İstatistikleri Örgün Eğitim 2016/17. T.C. Milli Eğitim Bakanlığı Strateji Geliştirme Başkanlığı. Ankara, Türkiye: Resmi İstatiktik Programı Yayını, ss.16-26, 2017.

[14] https://istatistik.yok.gov.tr/ (Erişim Tarihi: 14.12.2019)

[15] Kuyrukçu, Z. ve Uysal, M., Üniversite Kampüslerinde Fiziksel Değişimin İncelenmesi: Selçuk Üniversitesi Alaeddin Keykubat Kampüsü Örneği. Uluslararası Hakemli Tasarım ve Mimarlık Dergisi,2015, 06: 67-99. Doi: 10.17365/ TMD.2015614141

[16] https://www.yeditepe.edu.tr/tr/universitemiz-genel/yeditepe-universitesi (Erişim Tarihi: 11.11.2019)

[17] https://www.yeditepe.edu.tr/sites/default/files/images/yeditepe_university_ sustainability_report.pdf (Erişim Tarihi: 1.11.2019)

[18] Vitra Çağdaş Mimarlık Dizisi 3, Eğitim Yapıları, (Ed. İnat, B. ve Işsı, N.), A4 Ofset Matbaacılık, İstanbul, 2014.

[19] https://www.ekoyapidergisi.org/1748-piri-reis-universitesi-kampusu-olmasi-gerektigi-gibi-bir-kampus-binasi.html (Erişim Tarihi: 19.11.2019)

[20] https://www.arkiv.com.tr/proje/piri-reis-universitesi/2167)( https://www.pirireis.edu.tr/yesil-kampus (Erişim Tarihi: 19.11.2019)

[21] https://www.ozyegin.edu.tr/tr/hakkimizda/kurulus-oykusu (Erişim Tarihi: 23.11.2019)

[22] http://www.altensis.com/proje/ozyegin-universitesi-kampusu/ (Erişim Tarihi: 23.11.2019)

[23] http://www.mimarizm.com/mimari-projeler/egitim/uludag-universitesi-devlet-konservatuvari_113028 (Erişim Tarihi: 02.12.2019) 
[24] http://www.arkiv.com.tr/proje/tobb-etu-ogrenci-konukevi/8777 (Erişim Tarihi: 05.12.2019)

[25] http://www.cleanroomnews.org/sabanci-universitesi-nanoteknoloji-arastirma-ve-uygulama-merkezi-sunum (Erişim Tarihi: 09.12.2019)

[26] http://www.altensis.com/proje/sabanci-universitesi-nanoteknoloji-binasi/ (Erişim Tarihi: 09.12.2019)

[27] Kim, J.J. and Rigdon, B., Sustainable Architecture Module: Introduction to Sustainable Design, National Pollution Prevention Center for Higher Education, The University of Michigan, Ann Arbor, MI., 1998. 
